\title{
Pola Konsumsi Makanan Sumber Yodium dan Goitrogenik dengan GAKY pada Anak Usia Sekolah di Ponorogo
}

\section{lodine and Goitrogenic Intake among School Children in Ponorogo}

\author{
Imaniar Mahdiya Izati*1, ${ }^{*}$ Trias Mahmudiono ${ }^{1}$
}

\begin{abstract}
ABSTRAK
Latar Belakang: Gangguan Akibat Kekurangan Yodium (GAKY) merupakan salah satu masalah yang ada di Indonesia hingga saat ini. Rendahnya asupan yodium dan tingginya konsumsi sumber goitrogenik adalah penyebab terjadinya GAKY.

Tujuan: Untuk mengetahui faktor yang berhubungan terhadap kejadian GAKY pada anak usia sekolah.

Metode: Penelitian ini merupakan penelitian observasional analitik dengan desain case control dan dilakukan di Desa Sidoharjo, Kecamatan Jambon, Kabupaten Ponorogo pada bulan Mei 2017. Sampel penelitian ini yaitu siswa SDN IV Krebet dari kelas I-VI yang terdiri dari 62 siswa dimana 31 siswa menderita GAKY dan 31 siswa tidak menderita GAKY yang didapatkan dari hasil pemerikasaan palpasi. Pengumpulan data dilakukan menggunakan metode wawancara dengan kuesioner dan FFQ untuk mengetahui pola konsumsi makanan sumber yodium serta goitrogenik. Data dianalisis menggunakan chi square, fisher exact, korelasi spearman dan regresi logistik.

Hasil: Makanan sumber yodium yang jarang dikonsumsi oleh responden adalah ikan laut $(79,03 \%)$. Sedangkan makanan sumber goitrogenik yang sering dikonsumsi oleh responden adalah tiwul (48,39\%). Hasil uji regresi logistik menunjukkan bahwa faktor yang paling berpengaruh terhadap kejadian GAKY yaitu pola konsumsi ikan laut $(p=0,011)$.

Kesimpulan: Terdapat hubungan antara pola konsumsi ikan laut, pola konsumsi telur dan pola konsumsi tiwul dengan kejadian GAKY. Sebaliknya tidak terdapat hubungan antara karakteristik keluarga dengan kejadian GAKY.
\end{abstract}

Kata Kunci: anak usia sekolah, GAKY, goitrogenik, yodium 


\section{ABSTRACT}

Background: lodine deficiency disorders (IDD) is one of nutritional problem in Indonesia. Inadequate intake of iodine and excessive goitrogenic intake is are main cause of IDD.

Objectives: This study aimed to determine factors associated with IDD among schoolchildren.

Methods: This study was an observational analytic with case control design in Sidoharjo Village, Jambon Sub District, Ponorogo on May 2017. The sample was 62 students from the first - sixth grade of SDN IV Krebet. They are consist of 31 students suffer IDD and 31 students with non IDD measured from goiter palpation. The data was collected by interview using questionnaire, iodine and goitrogenic consumption using FFQ. Data were analyzed by using chi square, fisher exact, spearman correlation and logistic regression.

Results: Dietary iodine source that are rarely consumed is seafood (79,03\%). Dietary goitrogenic source that are often consumed is tiwul (48.39\%). Logistic regression analysis showed that seafood intake is the most influence factor of IDD $(\mathrm{p}=0.011)$.

Conclusion: There was a relation between iodine intake and goitrogenic intake with IDD among school children. Meanwhile, there is no association between characteristic of family with IDD among school children.

Keywords: School Children, IDD, goitrogenic, iodine

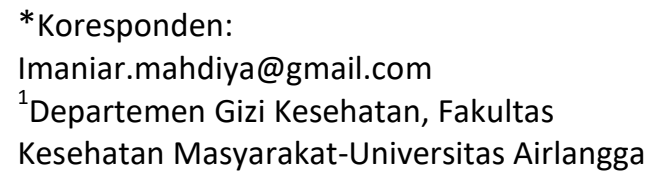

\section{PENDAHULUAN}

Gangguan Akibat Kekurangan Yodium (GAKY) yang terjadi pada anak dapat menurunkan kecerdasan anak. Anak yang kekurangan yodium memiliki IQ yang lebih rendah daripada anak yang sehat yaitu 15-20 poin lebih rendah ${ }^{1}$. GAKY sering terjadi di daerah pegunungan atau dataran tinggi dikarenakan lapisan tanah yang mengandung yodium terkikis ${ }^{2}$.

Prevalensi GAKY menurun dari tahun ke tahun. Pada tahun 2003, prevalensi GAKY di Indonesia sebesar 11,1 persen sedangkan prevalensi GAKY di Jawa Timur sebesar 24,8 persen ${ }^{3,4}$. Prevalensi GAKY di Kabupaten Ponorogo sebesar $12,27 \%{ }^{4}$. Berdasarkan hasil studi pendahuluan yang telah dilakukan angka TGR di Desa Sidoharjo sebesar 22,46\%. GAKY masih dianggap masalah kesehatan masyarakat, karena secara umum prevalensi masih di atas $5 \%{ }^{3}$.

Desa Sidoharjo merupakan sebuah desa yang berada di lereng perbukitan berkapur. Desa ini termasuk salah satu wilayah rawan
GAKY dengan dengan banyak kasus yaitu gondok, kretin dan gangguan fungsi mental ${ }^{5}$. Kondisi air dan tanah yang tidak mengandung yodium merupakan salah satu penyebab wilayah ini menjadi rawan GAKY. Berdasarkan penelitian yang dilakukan oleh Fuad dan Sunarto menunjukkan bahwa kadar yodium pada sumber mata air dan sedimen di tiaptiap sumber mata air di Desa Sidoharjo diketahui bahwa kadar iodium hampir tidak terdeteksi atau dapat dikatakan sangat rendah kadarnya yaitu kurang dari $0,6 \mathrm{ppm}^{6}$.

Selain itu, GAKY dapat disebabkan karena rendahnya konsumsi yodium dan tingginya konsumsi goitrogenik. Makanan yang tinggi yodium merupakan makanan yang juga tinggi protein seperti ikan laut, udang, kerang dan ganggang laut. Rendahnya konsumsi protein hewani disebabkan karena harga makanan sumber protein hewani yang tinggi ${ }^{7}$. Sebuah penelitian yang dilakukan oleh Patuti, et al., yang menunjukkan bahwa rendahnya konsumsi sumber protein akan menyebabkan seseorang berpeluang menderita GAKY 30,6 kali lebih besar 
dibandingkan dengan seseorang yang tidak menderita GAKY ${ }^{8}$.

Konsumsi makanan sumber goitrogenik yang tinggi disebabkan karena ketersediaannya yang melimpah. Sumber goitrogenik yang dapat dengan mudah ditemukan di Desa Sidoharjo yaitu singkong. Penduduk Desa Sidoharjo mengolah singkong menjadi tiwul yang menjadi makanan pokok pengganti nasi.

Berdasarkan uraian diatas, maka diperlukan adanya penelitian untuk mengetahui faktor yang berhubungan dengan kejadian GAKY pada anak usia sekolah di Desa Sidoharjo, Kecamatan Jambon, Kabupaten Ponorogo. Tujuan dari penelitian ini yaitu untuk mengetahui faktor yang berhubungan terhadap kejadian GAKY pada anak usia sekolah. Sedangkan manfaat penelitian ini yaitu untuk bahan pertimbangan memberikan kebijakan terkait penanggulangan GAKY khususnya pada anak usia sekolah

\section{METODE}

Penelitian ini dilakukan pada bulan Mei 2017 di Desa Sidoharjo, Kecamatan Jambon, Kabupaten Ponorogo dan telah dinyatakan lulus kaji etik. Penelitian ini merupakan penelitian observasional analitik dengan desain case control. Populasi dalam penelitian ini yaitu seluruh siswa Sekolah Dasar Negeri (SDN) IV Krebet. Populasi tersebut dipilih karena SDN IV Krebet memiliki jumlah siswa penderita GAKY paling banyak di Desa Sidoharjo. Besar sampel dihitung menggunakan rumus Lwanga dan Lemeshow dengan perbandingan $1: 1 \quad(\alpha=0,05 ; \beta=0,02)$ dan diperoleh besar sampel sebanyak 31 responden untuk masing-masing kelompok ${ }^{9}$.

Kriteria kasus pada penelitian ini adalah siswa SDN IV Krebet yang tinggal di Desa Sidoharjo dan menderita GAKY serta siswa mampu diajak komunikasi, sehat jasmani. Sedangkan kriteria kontrol pada penelitian ini yaitu siswa SDN IV Krebet yang tidak menderita GAKY dan tidak menderita penyakit gondongan.

Pengumpulan data menggunakan wawancara dengan kuesioner dan FFQ untuk mengetahui pola konsumsi sumber yodium dan goitrogenik. Bahan makanan yang tercantum dalam FFQ ditentukan dengan cara FGD yang dilakukan kepada beberapa ibu rumah tangga warga desa Sidoharjo. Bahan makanan yang dicantumkan dalam FFQ sumber yodium meliputi ikan air tawar, ikan laut, daging, susu, telur, bayam. Sedangkan bahan makanan yang dicantumkan dalam FFQ sumber goitrogenik meliputi sawi, singkong, daun singkong, kangkung, kubis, gambas, kol, terong ungu, kacang panjang, buncis, keripik gadung, gatot, tape, tiwul, keripik singkong dan jemblem. Kemudian dilakukan scoring dan dikelompokkan menjadi sering apabila total skor diatas skor rata-rata dan dikelompokkan menjadi jarang apabila nilai total skor dibawah skor rata-rata.

Teknik pengolahan dan analisis data menggunakan uji statistik chi square, fisher exact dan korelasi Spearman untuk mengetahui faktor yang berhubungan dengan kejadian GAKY pada anak usia sekolah. Analisis multivariat menggunakan uji regresi logistik untuk mengetahui faktor yang paling berpangaruh terhadap kejadian GAKY pada anak usia sekolah.

\section{HASIL DAN PEMBAHASAN}

Karakteristik keluarga responden yang tidak menderita GAKY dan menderita GAKY dapat dilihat pada tabel 1. Tidak ada hubungan antara karakteristik keluarga meliputi pendidikan ayah, pendidikan ibu, pendapatan, besar keluarga dengan kejadian GAKY pada anak usia sekolah. Sebanyak 30 responden $(48,39 \%)$ dari kedua kelompok mempunyai keluarga dengan kategori keluarga kecil dengan anggota keluarga $\leq 4$ orang. Hasil penelitian juga menunjukkan bahwa sebagian besar tingkat pendidikan ayah responden yaitu tamat SD (54,84\%). Sedangkan lebih dari $50 \%$ ibu responden mempunyai tingkat pendidikan yaitu tamat SD. Pekerjaan orangtua responden terbanyak sebagai petani. Sebanyak $(80,65 \%)$ ayah responden dan $(80,65 \%)$ ibu responden bekerja sebagai petani. 
Tabel 1. Karakteristik Keluarga Responden yang Tidak Menderita GAKY dan Menderita GAKY di SDN IV Krebet, Dusun Sidowayah, Desa Sidoharjo, Kecamatan Jambon, Kabupaten Ponorogo, Tahun 2017.

\begin{tabular}{|c|c|c|c|c|c|c|c|}
\hline \multirow{2}{*}{ Variabel } & \multicolumn{2}{|c|}{ Normal } & \multicolumn{2}{|c|}{ GAKY } & \multicolumn{2}{|c|}{ Total } & \multirow{2}{*}{$p$-valu } \\
\hline & $\mathrm{n}$ & $\%$ & $\mathbf{N}$ & $\%$ & $\mathbf{n}$ & $\%$ & \\
\hline \multicolumn{8}{|l|}{ Besar Keluarga } \\
\hline Kecil & 15 & 48,39 & 15 & 48,39 & 30 & 48,39 & \multirow{3}{*}{0,344} \\
\hline Sedang & 12 & 38,71 & 15 & 48,39 & 27 & 43,55 & \\
\hline Besar & 4 & 12,90 & 1 & 3,23 & 5 & 8,06 & \\
\hline \multicolumn{8}{|l|}{ Pendidikan Ayah } \\
\hline Tidak sekolah & 5 & 16,13 & 2 & 6,45 & 7 & 11,29 & \multirow{5}{*}{0,283} \\
\hline Tidak tamat SD & 8 & 25,82 & 6 & 19,35 & 14 & 22,58 & \\
\hline Tamat SD/MI & 14 & 45,16 & 20 & 64,52 & 34 & 54,84 & \\
\hline Tamat SMP/MTs & 4 & 12,9 & 2 & 6,45 & 6 & 9,68 & \\
\hline Tamat SMA/MA & 0 & 0 & 1 & 3,23 & 1 & 3,23 & \\
\hline \multicolumn{8}{|l|}{ Pendidikan Ibu } \\
\hline Tidak sekolah & 2 & 6,45 & 4 & 12,9 & 6 & 9,68 & \multirow{5}{*}{1,000} \\
\hline Tidak tamat SD & 2 & 6,45 & 1 & 3,23 & 3 & 4,84 & \\
\hline Tamat SD/MI & 23 & 74,19 & 24 & 77,42 & 47 & 75,81 & \\
\hline Tamat SMP/MTs & 4 & 12,9 & 1 & 3,23 & 5 & 8,06 & \\
\hline Tamat Perguruan Tinggi & 0 & 0 & 1 & 3.23 & 1 & 3,23 & \\
\hline \multicolumn{8}{|l|}{ Pekerjaan Ayah } \\
\hline PNS & 0 & 0 & 1 & 3,23 & 1 & 3,23 & \multirow{5}{*}{0,242} \\
\hline Pedagang/ wiraswasta & 2 & 6,45 & 1 & 3,23 & 3 & 4,84 & \\
\hline Petani/buruh tani & 26 & 83,87 & 24 & 77,42 & 50 & 80,65 & \\
\hline Tidak bekerja & 3 & 9,68 & 0 & 0 & 3 & 4,84 & \\
\hline Lain-lain (TKI) & 0 & 0 & 5 & 16,13 & 5 & 8,06 & \\
\hline \multicolumn{8}{|l|}{ Pekerjaan Ibu } \\
\hline Pegawai swasta & 0 & 0 & 1 & 3,23 & 1 & 80,65 & \multirow{5}{*}{0,923} \\
\hline Pedagang/ wiraswasta & 3 & 9,68 & 1 & 3,23 & 4 & 6,45 & \\
\hline Petani/buruh tani & 17 & 54,84 & 20 & 64,52 & 37 & 59,68 & \\
\hline Tidak bekerja (IRT) & 7 & 22,58 & 7 & 22,58 & 14 & 22,58 & \\
\hline Lain-lain (TKW) & 4 & 12,9 & 2 & 6,45 & 6 & 9,68 & \\
\hline
\end{tabular}

Sumber yodium yang jarang dikonsumsi oleh responden yaitu ikan laut. Sebanyak $79,03 \%$ responden dari kedua kelompok jarang mengonsumi ikan laut . Sedangkan sumber yodium yang sering dikonsumsi yaitu telur (40,32\%). Hasil uji statistik chi square dan fisher exact menunjukkan bahwa pola konsumsi sumber yodium yang berhubungan dengan kejadian GAKY yaitu pola konsumsi ikan laut $(p=0,004)$ dan telur $(p=0,010)$.
Sumber goitrogenik yang sering dikonsumsi oleh responden yaitu tiwul (48,39\%). Sedangkan sumber goitrogenik yang jarang dikonsumsi oleh responden yaitu gatot (93,55\%). Hasil uji statistik chi square dan fisher exact menunjukkan bahwa pola konsumsi sumber goitrogenik yang berhubungan dengan kejadian GAKY yaitu pola konsumsi tiwul $(p=0,005)$. Hasil selengkapnya dapat dilihat pada tabel 2 . 


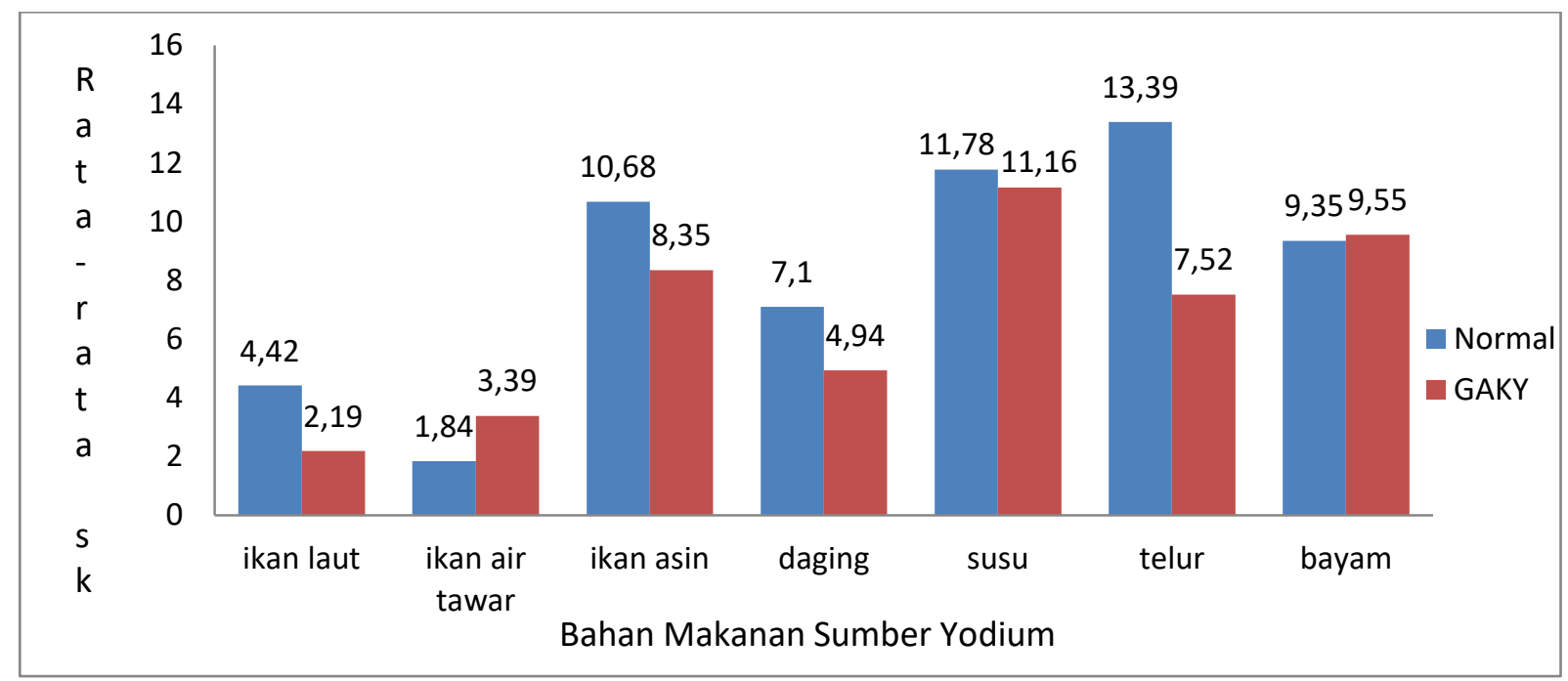

Gambar 1. Grafik Skor Rata-rata Pola Konsumsi Bahan Makanan Sumber Yodium

Tabel 2. Pola Konsumsi Sumber Yodium dan Pola Konsumsi Sumber Goitrogenik Responden yang Tidak Menderita GAKY dan Menderita GAKY di SDN IV Krebet, Dusun Sidowayah, Desa Sidoharjo, Kecamatan Jambon, Kabupaten Ponorogo, Tahun 2017.

\begin{tabular}{|c|c|c|c|c|c|c|c|c|c|c|}
\hline \multirow{2}{*}{ Variabel } & \multicolumn{2}{|c|}{ Normal } & \multicolumn{2}{|c|}{ GAKY } & \multicolumn{2}{|c|}{ Total } & \multirow{2}{*}{$p$-value } & \multirow{2}{*}{ OR } & \multicolumn{2}{|c|}{$95 \% \mathrm{Cl}$} \\
\hline & $n$ & $\%$ & $n$ & $\%$ & $\mathbf{N}$ & $\%$ & & & lower & upper \\
\hline \multicolumn{11}{|l|}{$\begin{array}{l}\text { Pola konsumsi } \\
\text { sumber yodium }\end{array}$} \\
\hline $\begin{array}{l}\text { Pola konsumsi } \\
\text { ikan laut }\end{array}$ & & & & & & & $0,004^{*}$ & 0,125 & 0.025 & 0,628 \\
\hline Jarang & 20 & 64,52 & 29 & 93,55 & 49 & 79,03 & & & & \\
\hline Sering & 11 & 35,48 & 2 & 6,46 & 13 & 20,97 & & & & \\
\hline $\begin{array}{l}\text { Pola konsumsi } \\
\text { ikan air tawar }\end{array}$ & & & & & & & 0,786 & 1,34 & 0,462 & 3,916 \\
\hline Jarang & 22 & 70,97 & 2011 & 64,52 & 42 & 67,74 & & & & \\
\hline Sering & 9 & 29,03 & & 35,48 & 20 & 32,26 & & & & \\
\hline \multicolumn{11}{|l|}{ Pola konsumsi } \\
\hline ikan asin & & & 24 & & & & 0,401 & 0,530 & 0,173 & 1,622 \\
\hline Jarang & 20 & 64,52 & 7 & 77,42 & 44 & 70,97 & & & & \\
\hline Sering & 11 & 35,48 & & 22,58 & 18 & 29,03 & & & & \\
\hline \multicolumn{11}{|l|}{ Pola konsumsi } \\
\hline Jarang & 22 & 70,97 & 9 & 70,97 & 44 & 70,97 & & & & \\
\hline Sering & 9 & 29,03 & & 29,03 & 18 & 29,03 & & & & \\
\hline \multicolumn{11}{|l|}{ Pola konsumsi } \\
\hline susu & & & 22 & & & & 0,772 & 1,403 & 0,446 & 4,406 \\
\hline Jarang & 24 & 77,42 & 9 & 70,97 & 46 & 74,19 & & & & \\
\hline Sering & 7 & 22,58 & & 29,03 & 16 & 25,81 & & & & \\
\hline \multicolumn{11}{|l|}{ Pola konsumsi } \\
\hline telur & & & 24 & & & & $0,010^{*}$ & 0,211 & 0,070 & 0,635 \\
\hline Jarang & 13 & 41,94 & 7 & 77,42 & 37 & 59,68 & & & & \\
\hline Sering & 18 & 58,06 & & 22,58 & 25 & 40,32 & & & & \\
\hline \multicolumn{11}{|l|}{ Pola konsumsi } \\
\hline bayam & & & 22 & & & & 1,000 & 1,176 & 0,385 & 3,595 \\
\hline Jarang & 23 & 74,19 & 9 & 77,42 & 45 & 72,58 & & & & \\
\hline Sering & 8 & 25,81 & & 22,58 & 17 & 27,42 & & & & \\
\hline
\end{tabular}




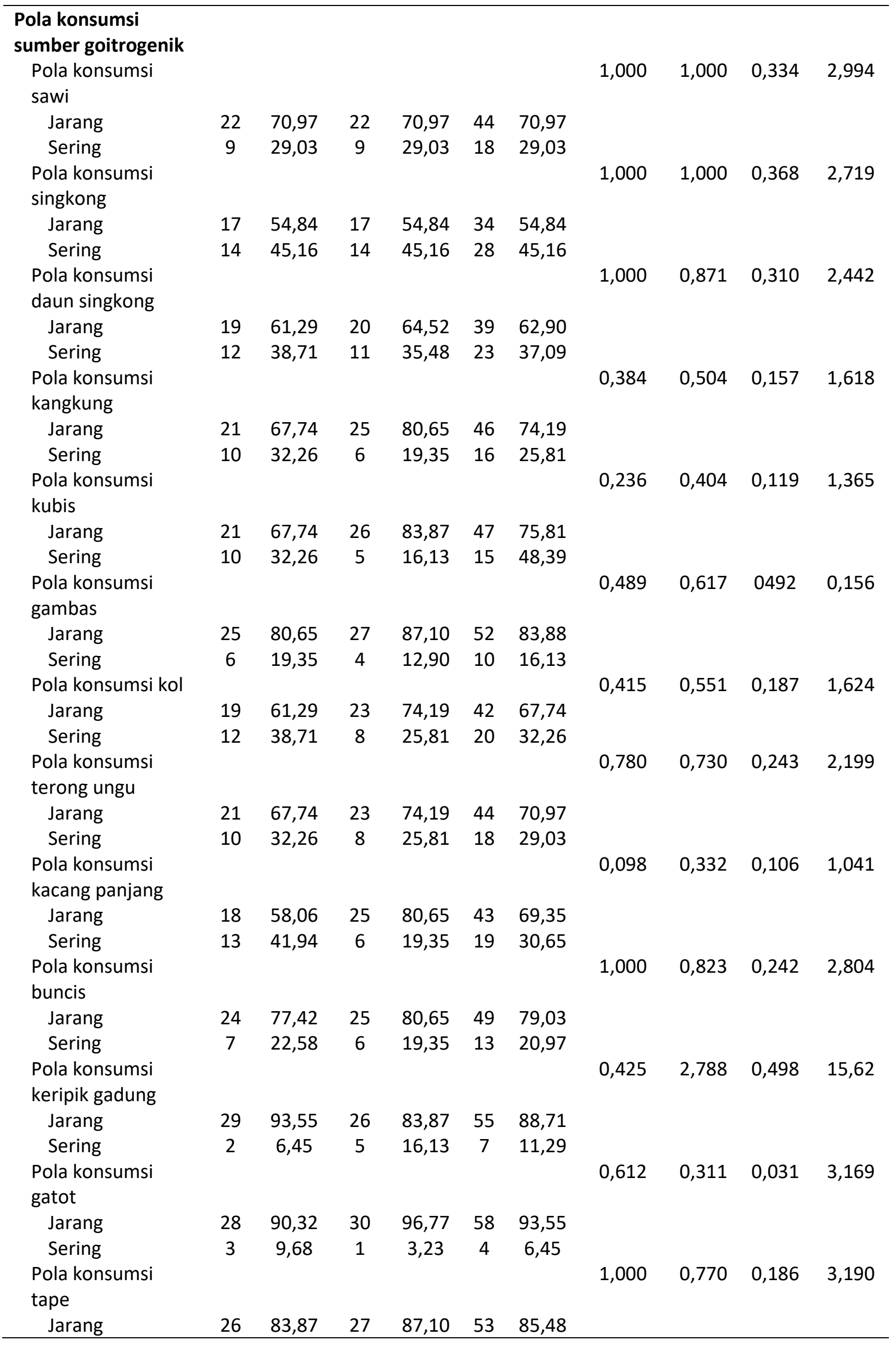




\begin{tabular}{lccccccccccc}
\hline $\begin{array}{l}\text { Sering } \\
\text { Pola konsumsi } \\
\text { tiwul }\end{array}$ & 5 & 16,13 & 4 & 12,90 & 9 & 14,52 & & & & \\
$\quad$ Jarang & 22 & 70,97 & 10 & 32,26 & 32 & 51,61 & & & & \\
$\quad$ Sering & 9 & 29,03 & 21 & 67,74 & 30 & 48,39 & & & & \\
$\begin{array}{l}\text { Pola konsumsi } \\
\text { keripik singkong }\end{array}$ & & & & & & & & & & & \\
$\quad$ Jarang & 27 & 87,10 & 24 & 77,42 & 51 & 82,26 & & & \\
$\quad$ Sering & 4 & 12,90 & 7 & 22,58 & 11 & 17,74 & & & & \\
$\quad \begin{array}{l}\text { Pola konsumsi } \\
\text { jemblem }\end{array}$ & & & & & & & & & & \\
$\quad$ Jarang & 17 & 54,84 & 17 & 54,84 & 34 & 54,84 & & & & \\
$\quad$ Sering & 14 & 45,16 & 14 & 45,16 & 28 & 45,16 & & & & \\
\hline
\end{tabular}

Uji chi square dengan $\alpha=0,05$ dan $(*)$ bermakna pada $p<0,05$

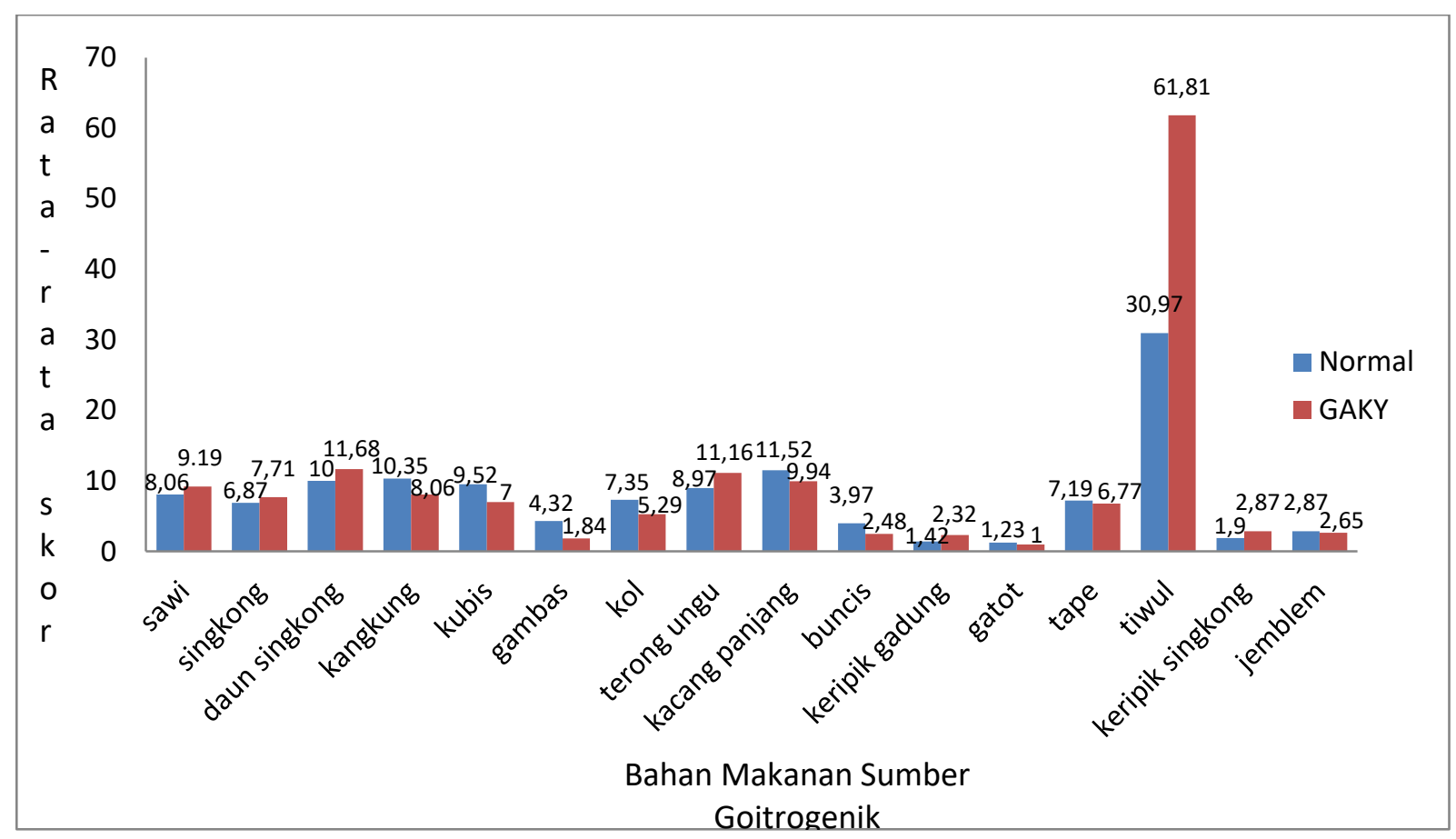

Gambar 2. Grafik Skor Rata-rata Pola Konsumsi Bahan Makanan Sumber Goitrogenik

Dari ketiga variabel yang berhubungan dengan kejadian GAKY kemudian dianalisis menggunakan uji regresi logistik. Hasil uji regresi logistik menunjukkan bahwa faktor yang paling berpengaruh terhadap GAKY yaitu pola konsumsi ikan laut $(p=0,011)$. Hasil selengkapnya dapat dilihat pada tabel 3 .

Berdasarkan uji statistik chi square, fisher exact dan korelasi spearman dapat diketahui bahwa karakteristik keluarga meliputi besar keluarga, pendidikan ayah, pendidikan ibu, pekerjaan ayah dan pekerjaan ibu tidak berhubungan dengan kejadian GAKY pada anak usia sekolah. Hal ini sejalan dengan penelitian yang dilakukan oleh Abebe et al pada tahun 2017 di Ethiopia yang menunjukkan bahwa tidak terdapat hubungan antara besar keluarga dan pekerjaan orangtua dengan kejadian GAKY pada anak usia sekolah 10. Penelitian lain yang dilakukan oleh Hariyanti dan Indrawati pada tahun 2013 di Kabupaten Ngawi menunjukkan bahwa tidak ada hubungan antara pendidikan orangtua dengan kejadian GAKY pada anak usia sekolah 11. Penelitian sejenis yang dilakukan oleh Djayusmantoko menunjukkan bahwa jumlah anggota keluarga, pekerjaan kepala keluarga dan pendidikan kepala keluarga tidak berhubungan dengan kejadian GAKY pada anak usia sekolah ${ }^{12}$. 
Tabel 3. Hasil Uji Regresi Logistik Pola Konsumsi Sumber Yodium dan Pola Konsumsi Sumber Goitrogenik

\begin{tabular}{|c|c|c|c|}
\hline Variabel & $p$-value & OR & $95 \% \mathrm{Cl}$ \\
\hline $\begin{array}{l}\text { Pola konsumsi } \\
\text { ikan laut }\end{array}$ & 0,011 & 4,634 & $1,423-15,087$ \\
\hline $\begin{array}{l}\text { Pola konsumsi } \\
\text { telur }\end{array}$ & 0,364 & 0,364 & $0,108-1,227$ \\
\hline $\begin{array}{l}\text { Pola konsumsi } \\
\text { tiwul }\end{array}$ & 0,106 & 0,361 & $0,105-1,234$ \\
\hline
\end{tabular}

Sumber yodium yang paling jarang dikonsumsi oleh responden yaitu ikan laut. Hal ini dikarenakan letak desa yang berada di perbukitan dan jarak dari desa ke pasar induk yang cukup jauh menyebabkan konsumsi pangan masyarakat terbatas pada pangan yang tersedia. Sebagian besar kandungan yodium dalam makanan dan minuman termasuk dalam kategori rendah. Sedangkan kandungan yodium pada ikan laut lebih tinggi karena yodium yang terdapat pada air laut terkonsentrasi pada hewan dan tumbuhan laut ${ }^{13}$. Selain itu, kandungan yodium dalam bahan makanan bervariasi dan dipengaruhi oleh letak geografis, musim dan cara memasaknya ${ }^{14}$.

Hasil uji statistik chi square didapatkan nilai signifikansi sebesar 0,004 dan menunjukkan adanya hubungan antara pola konsumsi ikan laut dengan kejadian GAKY. Penelitian ini sejalan dengan penelitian yang dilakukan oleh Alfitri et al, yang menunjukkan bahwa ibu hamil yang mengonsumsi ikan laut lebih rendah berpeluang menderita GAKY 3,44 kali lebih besar dibandingkan dengan tingkat konsumsi ikan laut yang tinggi ${ }^{15}$. Penelitian yang dilakukan oleh Patuti et al pada tahun 2010 yang menunjukkan bahwa rendahnya konsumsi sumber protein menyebabkan seseorang berpeluang menderita GAKY 30,6 kali lebih besar dibandingkan dengan seseorang yang tidak menderita GAKY ${ }^{8}$. Penelitian lain yang dilakukan oleh Dardjito dan Raharjo pada wanita usia subur yang menunjukkan bahwa penyebab langsung kejadian GAKY pada adalah kurangnya asupan yodium yang dikonsumsi sehari-hari ${ }^{16}$.

Gangguan akibat kekurangan yodium akan timbul apabila konsumsi yodium kurang dari kebutuhan. Apabila konsumsi yodium kurang maka akan berakibat pada kelenjar tiroid yang tidak mampu untuk mensekresi hormon tiroid. Hormon tiroid dibutuhkan untuk perkembangan otak yang optimal. Di daerah yang kekurangan yodium dan rendahnya kadar hormon tiroid seseorang akan mengakibatkan terganggunya perkembangan otak. Keadaan yang lebih parah akan mengakibatkan kretinisme, kerusakan otak dan penurunan kapasitas kognitif yang mempungaruhi seluruh populasi. Akibatnya kemampuan mental anak-anak dan orang dewasa yang tinggal di daerah tersebut akan berkurang dibandingkan dengan daerah lain ${ }^{2}$.

Rendahnya asupan yodium disertai tingginya asupan zat goitrogenik menyebabkan peluang terjadinya GAKY semakin besar ${ }^{12}$. Berdasarkan hasil penelitian, makanan sumber goitrogenik yang sering dikonsumsi oleh kelompok responden yang menderita GAKY adalah tiwul. Hal ini dikarenakan tiwul merupakan makanan pokok penduduk. Tiwul terbuat dari singkong yang dikeringkan dan ditumbuk. Zat goitrogenik yang terkandung dalam singkong yaitu tiosionat. Tiosianat merupakan salah satu zat goitrogenik yang menghambat transport aktif yodium ke dalam kelenjar tiroid ${ }^{17}$.

Hasil dari penelitian ini sejalan dengan penelitian yang dilakukan oleh Hariyanti dan Indrawati yang menunjukkan bahwa terdapat hubungan yang kuat antara konsumsi sumber goitrogenik dengan kejadian GAKY ${ }^{11}$. Penelitian yang dilakukan oleh Santoso et al, menunjukkan bahwa terdapat hubungan antara asupan goitrogenik tiosianat dengan kadar yodium dalam urin pada ibu hamil ${ }^{18}$. Kadar yodium dalam urin menunjukkan status yodium seseorang. Seringnya mengonsumsi sumber goitrogenik dapat menghambat absorpsi dan metabolisme yodium dalam tubuh. Zat goitrogenik menghasilkan senyawa yang bersaing dengan kelenjar tiroid untuk mengambil yodium ${ }^{19}$. Penelitian lain yang dilakukan oleh Kusuma dan Budiono di Kabupaten Temanggung menunjukkan bahwa faktor konsumsi sumber goitrogenik berhubungan dengan kejadian GAKY pada anak usia sekolah ${ }^{19}$. Penelitian lain yang dilakukan oleh Mezgebu et al pada anak usia 
6-12 tahun di Ethiopia yang menyatakan bahwa anak yang sering mengonsumsi sumber goitrogenik yaitu kubis lebih berpeluang terkena gondok dibandingkan anak yang tidak pernah mengonsumsi kubis ${ }^{20}$.

Hasil analisis uji regresi logistik menunjukkan bahwa faktor yang paling berpengaruh terhadap kejadian GAKY adalah pola konsumsi ikan laut. Anak usia sekolah yang jarang mengonsumsi ikan laut mempunyai risiko 4,634 kali lebih besar untuk mengalami GAKY dibandingkan dengan anak usia sekolah yang sering mengonsumsi ikan laut setelah dikontrol variabel pola konsumsi telur dan pola konsumsi tiwul.

\section{KESIMPULAN}

Kesimpulan dari penelitian ini yaitu faktor yang berhubungan dengan kejadian GAKY pada anak usia sekolah di Desa Sidoharjo yaitu pola konsumsi ikan laut, pola konsumsi telur dan pola konsumsi tiwul. Faktor yang paling berpengaruh terhadap kejadian GAKY adalah pola konsumsi ikan laut.

\section{ACKNOWLEDGEMENT}

Penghargaan diberikan penulis kepada seluruh staf pengajar program studi sarjana ilmu gizi Universitas Airlangga atas bimbingan dan dukungan yang telah diberikan.

\section{REFERENSI}

1. Badan Perencanaan Pembangunan Nasional. Rencana Aksi Nasional Pangan dan Gizi 2010. Jakarta: Badan Perencanaan Pembangunan Nasional; 2007. p. 5.

2. World Health Organization. Assesment of iodine deficiency disorders and monitoring their elimination. Geneva: WHO; 2007 p. 6-7

3. Badan Perencanaan Pembangunan Nasional. Rencana Aksi Nasional Kesinambungan Program Penanggulangan GAKY. Jakarta: Badan Perencanaan Pembangunan Nasional; 2004. p.4.

4. Dinas Kesehatan Provinsi Jawa Timur. Profil Kesehatan Jawa Timur 2009.
Surabaya: Dinas Kesehatan Provinsi Jawa Timur; 2008. p.48

5. Siswono. 2010. Help Out GAKY. Available at: http://gizi.depkes.go.id/help-out-gaky Diakses pada tanggal 8 Juli 2017

6. Fuad, $\mathrm{F}$ dan Sunarto. Kandungan Logam Berat dan Kadar Yodium Pada Sumber Mata Air (Suatu Analisis Terhadap Faktor Terjadinya Down Syndrome dengan Metode Atomic Absorbtion Spectrofotometry (AAS) Pada Masyarakat "Kampung Idiot" Sidowayah). Jurnal Ekosains 2015; 7(2)

7. Patuti N, Sudargo T, Wachid DN. Faktorfaktor yang berhubungan dengan Kejadian GAKY pada Anak Sekolah Dasar di Pinggiran Pantai Kota Palu Provinsi Sulawesi Tengah. Jurnal Gizi Klinik Indonesia 2010; 7(1):17-26.

8. Lwanga S.K dan Lemeshow S. 1991. Sample Size Determination in Health Studies. Geneva: WHO.

9. Pebriana A. Hubungan Asupan Protein dan Yodium dengan Kejadian Gondok pada Anak SD Pringapus dan SD Kataan Kecamatan Ngadirejo Kabupaten Temanggung. Skripsi. Ungaran: Sekolah Tinggi Ilmu Kesehatan Ngudi Waluyo Ungaran; 2016. p. 58.

10. Abebe Z, Gebeye E, Tariku A. Poor Dietary Diversity, Wealth Status and Use of Unlodized Salt are Associated with Goiter among School Children: A Cross-Sectional Study in Ethiopia. BMC Public Health 2017; 17(44): 1-11.

11. Hariyanti $W$, Indrawati V. Faktor-Faktor yang Mempengaruhi Kejadian Gaky pada Anak Usia Sekolah Dasar di Kecamatan Kendal Kabupaten Ngawi. Ejournal Boga; 2013. 2(1): 150-158.

12. Djayusmantoko, Hadi $H$, Julia $M$. Konsumsi Zat Yodium dan Zat Goitrogenik sebagai Faktor Resiko GAKY pada Anak Sekolah Dasar di Kecamatan Tabir Ulu, Kabupaten Maringin, Provinsi Jambi. Jurnal Sains Kesehatan 2005; 18(1):139145

13. Zimmerman $M$, Trumbo PR. lodine. American Society for Nutrition. Advances in Nutrition.2012; 8(4):262-264. 
14. Sulistiyani $R$, Rahayuningsih $H M$. Gambaran Konsumsi Garam lodium, Kadar TSH (Tyroid Stimulating Hormon) dan Kadar UIE (Urine lodium Excretion) pada Ibu Hamil. Journal of Nutrition Collage. 2013; 2(4): 720-729.

15. Alfitri, Widodo SU, Sudargo T. Faktorfaktor pada Kejadian GAKY Ibu Hamil di Tabunganen Barito Kuala, Kalimantan Selatan. Jurnal Gizi dan Dietetik Indonesia. 2013; 1(1): 7-14.

16. Patuti N, Sudargo T, Wachid DN. Faktorfaktor yang berhubungan dengan Kejadian GAKY pada Anak Sekolah Dasar di Pinggiran Pantai Kota Palu Provinsi Sulawesi Tengah. Jurnal Gizi Klinik Indonesia 2010; 7(1):17-26.

17. Dardjito E, Rahardjo S. Gangguan Akibat Kekurangan Yodium pada Wanita Usia Subur di Kecamatan Baturaden Kabupaten Banyumas, Jawa Tengah. Jurnal Kesehatan Masyarakat Nasional 2010; 5(3):105-109.

18. Firdanisa, R. Hubungan antara Konsumsi Sianida Makanan dengan Ekskresi lodium
Urin pada Anak Sekolah Dasar di Daerah Endemik GAKI. Skripsi. Semarang: Fakultas Kedokteran Universitas Diponegoro, 2011. p.47.

19. Santoso EB, Hadi H, Sudargo T. Hubungan antara Konsumsi Makanan Goitrogenik dan Status lodium pada Ibu Hamil di Kecamatan Endemis Gangguan Akibat Kekurangan lodium. Berita Kedokteran Masyarakat. 2006; 22(3):93-99.

20. Kusuma ST, Budiono I. Faktor Konsumsi yang berhubungan dengan Kejadian Gangguan Akibat Kekurangan Yodium pada Anak Sekolah Dasar (Studi Kasus di MI Depokharjo Parakan Kabupaten Temanggung). Unnes Journal of Public Health 2016; 5(2):149-155.

21. Mezgebu Y, Mossie A, Rajesh PN, Beyene G. Prevalence and Severity of lodine Deficiency Disorder among Children 6-12 Years of Age in Shebe Senbo District, Jimma Zone, Southwest Ethiopia. Ethiop J Health Sci. 2012; 22(3):196-204. 